\title{
Identifikasi struktur kognitif siswa dengan menggunakan peta konsep pada larutan asam-basa
}

\author{
Bela Ganda ${ }^{* a}$ John Z. Lombok, Jenny Kumajas ${ }^{a}$ \\ a Universitqs Negeri Manado, Tondano, 95618, Indonesia
}

\begin{tabular}{|c|c|}
\hline I NFO ARTIKEL & ABSTRACT \\
\hline Diterima 23 Mei 2019 & Every student has different cognitive structures, but few teachers realize these \\
\hline Disetujui 20 Juni 2019 & $\begin{array}{l}\text { differences. The purpose of this research is to identify students' cognitive structures, } \\
\text { which comprise of several aspects such as content, students' prior knowledge, new }\end{array}$ \\
\hline Key word: & knowledge and misconception when they learn from a concept map. The method used \\
\hline Cognitive Structures, & is descriptive research, conducted on 18 students at a senior high school in Manado \\
\hline Concept Map, & City. The students' cognitive structures are revealed using questions from concept \\
\hline Acid-Base Solution & map about acid-base solution. The cognitive structures are identified based on the \\
\hline Kata kunci: & scores obtained by each students from the concept map questions. The result shows \\
\hline Struktur kognitif, & three cognitive categories of students on the content aspect, namely poor, good, and \\
\hline Peta konsep, & excellent, and three categories of students' cognitive structures, which are students' \\
\hline Larutan asam-basa & $\begin{array}{l}\text { prior knowledge, new knowledge and misconception. In general, the students' } \\
\text { cognitives structure are categorized as good. }\end{array}$ \\
\hline
\end{tabular}

\begin{tabular}{|c|c|}
\hline & ABSTRAK \\
\hline $\begin{array}{l}\text { *e-mail: } \\
\text { gandabela28@gmail.com }\end{array}$ & $\begin{array}{l}\text { Setiap siswa memiliki struktur kognitif yang berbeda-beda, namun } \\
\text { kebanyakan guru belum mengetahui perbedaan tersebut. Tujuan penelitian } \\
\text { ini adalah untuk mengidentifikasi struktur kognitif siswa meliputi aspek isi, } \\
\text { apa yang telah diketahui siswa, apa yang belum diketahui siswa, dan } \\
\text { miskonsepsi yang terjadi pada siswa dengan menggunakan peta konsep. } \\
\text { Metode penelitian yang digunakan adalah metode penelitian deskriptif, pada } \\
18 \text { siswa di salah satu SMA di Kota Manado. Struktur kognitif siswa diungkap } \\
\text { menggunakan soal peta konsep mengenai Larutan asam-basa. Struktur } \\
\text { kognitif siswa diidentifikasi berdasarkan skor yang diperoleh tiap siswa pada } \\
\text { setiap soal pada peta konsep. Ditemukan tiga kategori kognitif siswa pada } \\
\text { aspek isi, yaitu kurang, baik, dan baik sekali dan tiga kategori struktur } \\
\text { kognitif siswa yaitu mengenai apa yang telah diketahui siswa, apa yang } \\
\text { belum diketahui siswa, serta miskonsepsi yang terjadi pada siswa. Secara } \\
\text { umum struktur kognitif siswa dikategorikan baik. }\end{array}$ \\
\hline
\end{tabular}

\section{Pendahuluan}

Kimia merupakan salah satu pelajaran yang dianggap sulit oleh siswa SMA, karena banyak simbol kimia, reaksi kimia yang rumit, dan prinsip-prinsip kimia teoritis. Atom, molekul, elektron, dan ikatan kimia yang merupakan hal mendasar dalam pembelajaran kimia yang tidak nampak dan tidak dapat dialami secara langsung. Selain itu, kimia mengandung konsep yang bersifat kompleks dan mempunyai tingkat generalisasi yang tinggi, sehingga siswa membentuk pemahamannya sendiri yang berdasarkan pengalamannya bukan secara teoritis.

Siswa yang mengalami kesulitan belajar kimia tidak akan dapat membangun konsep yang bersifat hirarki. Setiap individu memiliki cara berpikir yang berbeda-beda dan cara pengolahan informasi yang berbeda-beda pula, yang artinya siswa memiliki struktur kognitif yang berbeda-beda [1].

Salah satu pernyataan dalam teori Ausubel adalah bahwa faktor yang paling penting yang mempengaruhi pembelajaran adalah apa yang 
telah diketahui siswa (pengetahuan awal). Tes kertas dan pensil tradisional banyak digunakan untuk menilai pengetahuan siswa yang ada dalam pendidikan kimia [1]. Tapi tes ini tidak bisa mendapatkan informasi lebih lanjut tentang hubungan antara konsep-konsep dalam memori mereka. sehingga eksplorasi struktur kognitif peserta didik dapat menjadi indikator penting dalam menilai apa yang diketahui pelajar. Ausubel belum menyediakan suatu alat atau cara yang sesuai yang dapat digunakan guru untuk mengetahui apa yang telah diketahui oleh para siswa [2]. Cara untuk mengetahui konsep-konsep yang telah dimiliki siswa supaya belajar bermakna berlangsung, dapat dilakukan dengan pertolongan peta konsep.

Struktur kognitif adalah membangun hipotetis yang menunjukkan konsep dalam ingatan jangka panjang peserta didik dan hubungannya [3]. Pentingnya membangun hipotetis ini sebagai faktor utama dalam akumulasi pengetahuan: "Jika struktur kognitif yang ada jelas, stabil, dan sesuai terorganisir, itu memfasilitasi pembelajaran dan retensi materi pelajaran baru. Dalam paradigma konstruktivisme, pengetahuan tidak dapat langsung ditransmisikan tetapi harus secara aktif dibangun oleh seorang individu [4].

Menurut Gagne istilah "cognitive" berasal dari kata cognition artinya adalah pengertian, mengerti, kognitif adalah proses yang terjadi secara internal di dalam pusat susunan saraf pada saat manusia sedang berpikir [5]. Struktur kognitif menurut Pikaget adalah mental framework yang dibangun seseorang dengan mengambil informasi dari lingkungan dan menginterpretasikan, mengorganisasikan, serta mentransformasikannya [6].

Peta konsep adalah suatu alat yang digunakan untuk mengatur dan merepresentasikan suatu pengetahuan. Atas dasar teori Ausubel, Novak mengemukakan gagasan peta konsep yang menyatakan hubungan antara konsep-konsep untuk menolong guru mengetahui konsep-konsep yang telah dimiliki para siswa agar belajar bermakna dapat berlangsung [2].

Teknik evaluasi peta konsep masih jarang diterapkan, maka dalam penelitian ini peta konsep diterapkan sebagai alat evaluasi untuk mengukur struktur kognitif siswa. Penelitian ini bertujuan untuk mengidentifikasi struktur kognitif siswa dengan menggunakan peta konsep pada larutan asam-basa.

\section{Metode}

Metode penelitian yang digunakan adalah metode penelitian deskriptif. Fokus penelitian deskriptif bukan pada bagaimana menemukan hubungan penyebab dan pengaruh, tapi sebaliknya untuk mendeskripsikan hubunganhubungan yang ada antara variabel-variabel.

Penelitian ini dilaksanakan di SMA Pioneer Manado pada bulan April 2017 di kelas XI IPA 1. subyek penelitian sebanyak 18 siswa. Pada tes ini siswa diminta untuk membuat peta konsep dengan daftar konsep yang telah disediakan pada soal, kemudian siswa menentukan konsep yang paling umum dari daftar konsep yang telah tersedia, lalu menulis hubungan yang terdekat dengan konsep yang paling umum yang telah ditentukan sebelumnya, dan menambahkan konsep lain yang tersisa dari daftar pada peta konsep. Konsep-konsep tersebut dihubungkan dengan sebuah garis penghubung disertai keterangan (label) yang tepat dan sesuai dengan pemahaman mereka.

Instrumen yang digunakan dalam penelitian ini berupa soal peta konsep dan Master peta konsep. Peta konsep hasil buatan siswa masing-masing dinilai kecocokan - peta konsep hasil buatan siswa dibandingkan dengan master peta konsep kemudian dinilai proposisinya yang cocok saja.

Sebelum instrumen digunakan, instrumen telah diuji terlebih dahulu dengan menggunakan uji validitas. Uji validitas dilakukan untuk mengetahui apakah instrumen yang digunakan layak atau tidak. Validitas instrumen diperoleh dengan validitas Judgement ahli, dan diberi skor oleh ahli selanjutnya diolah dan dianalis validitas isinya dengan menggunakan formula Aiken's V.

Struktur kognitif siswa diidentifikasi dengan menggunakan peta konsep hasil buatan siswa, dengan indikator yang diidentifikasi sebagai berikut:

a. Kognitif siswa berdasarkan aspek isi

b. Konsep-konsep asam-basa yang telah diketahui siswa 
c. Konsep-konsep asam-basa yang belum diketahui siswa

d. Kesalahpahaman siswa terhadap konsep larutan asam-basa

\section{Hasil dan Pembahasan Hasil Penelitian}

Berdasarkan teknik pengumpulan data yang digunakan dalam penelitian, maka data penelitian diperoleh dengan menggunakan peta konsep kepada siswa kelas XI SMA Pioner Manado yang berjumlah 18 orang sebagai subjek penelitian, maka diperoleh hasil yang ditunjukkan pada Tabel 1.

Identifikasi yang dilakukan peneliti diawali dengan menganalisis presentase setiap link. Kemudian menganalisis frekuensi link pada kluster utama. Selanjutnya karakteristik konsepsi siswa dapat digambarkan dalam lima kategori konsepsi siswa yang diidentifikasi dari hasil tes peta konsep larutan asam-basa.

Tabel 1. Hasil tes peta konsep

\begin{tabular}{cccc}
\hline \multirow{2}{*}{ No. } & \multirow{2}{*}{ Sampel } & \multicolumn{2}{c}{ Hasil } \\
\cline { 3 - 4 } & & Proporsi & Nilai \\
\hline 1. & AR & 40 & 100 \\
\hline 2. & FL & 40 & 100 \\
\hline 3. & LR & 40 & 100 \\
\hline 4. & RR & 37 & 92,5 \\
\hline 5. & ML & 33 & 82,5 \\
\hline 6. & AG & 11 & 27,5 \\
\hline 7. & PS & 40 & 100 \\
\hline 8. & AM & 32 & 80 \\
\hline 9. & IP & 40 & 100 \\
\hline 10. & VP & 40 & 100 \\
\hline 11. & GM & 12 & 30 \\
\hline 12. & SH & 40 & 100 \\
\hline 13. & NR & 36 & 90 \\
\hline 14. & BL & 32 & 80 \\
\hline 15. & MK & 18 & 45 \\
\hline 16. & TN & 29 & 70,5 \\
\hline 17. & AP & 28 & \\
\hline 18. & MN & 34 & \\
\hline & & & 40 \\
\hline
\end{tabular}

Tabel 2 menyajikan presentasi perbedaan tipe link yang digunakan siswa. Enam kategori tipe link meliputi: (1) Jenis (type of), (2) bagian dari (part to), (3) petunjuk (lead to), (4) sifat (characteristic), (5) bukti (evidence), (6) sama dengan (analogy).

Tabel 2. Presentase Setiap Link yang ditulis beberapa siswa

\begin{tabular}{ccccccc}
\hline Siswa & $\begin{array}{c}\text { Total } \\
\text { Link }\end{array}$ & $\begin{array}{c}\text { Link } \\
(\%)\end{array}$ & $\begin{array}{c}\text { Link } \\
(\%) \\
\text { denis } \\
\text { Bagian } \\
\text { dari }\end{array}$ & $\begin{array}{c}\text { Link }(\%) \\
\text { petunjuk }\end{array}$ & $\begin{array}{c}\text { Link } \\
(\%) \\
\text { sifat }\end{array}$ & $\begin{array}{c}\text { Link } \\
(\%)\end{array}$ \\
\hline Bukti \\
FL & 10 & $100 \%$ & $100 \%$ & $100 \%$ & $100 \%$ & $100 \%$ \\
LR & 10 & $100 \%$ & $100 \%$ & $100 \%$ & $100 \%$ & $100 \%$ \\
RR & 11 & $100 \%$ & $100 \%$ & $100 \%$ & $100 \%$ & $100 \%$ \\
ML & 10 & $0.00 \%$ & $100 \%$ & $100 \%$ & $100 \%$ & $0.00 \%$ \\
AG & 11 & $0.00 \%$ & $0.00 \%$ & $0.00 \%$ & $60.66 \%$ & $0.00 \%$ \\
PS & 10 & $100 \%$ & $100 \%$ & $100 \%$ & $100 \%$ & $100 \%$ \\
AM & 10 & $100 \%$ & $100 \%$ & $100 \%$ & $60.66 \%$ & $0.00 \%$ \\
GM & 10 & $50 \%$ & $100 \%$ & $0.00 \%$ & $100 \%$ & $100 \%$ \\
SH & 10 & $100 \%$ & $100 \%$ & $100 \%$ & $100 \%$ & $100 \%$ \\
NR & 10 & $100 \%$ & $100 \%$ & $100 \%$ & $100 \%$ & $100 \%$ \\
BL & 10 & $100 \%$ & $100 \%$ & $100 \%$ & $30.33 \%$ & $100 \%$ \\
MK & 10 & $50 \%$ & $0.00 \%$ & $0.00 \%$ & $100 \%$ & $0.00 \%$ \\
TN & 10 & $100 \%$ & $100 \%$ & $0.00 \%$ & $100 \%$ & $0.00 \%$ \\
AP & 10 & $50 \%$ & $100 \%$ & $0.00 \%$ & $60.66 \%$ & $100 \%$ \\
MN & 9 & $100 \%$ & $100 \%$ & $100 \%$ & $60.66 \%$ & $100 \%$ \\
IP & 10 & $100 \%$ & $100 \%$ & $100 \%$ & $100 \%$ & $100 \%$ \\
VP & 10 & $100 \%$ & $100 \%$ & $100 \%$ & $100 \%$ & $100 \%$ \\
\hline
\end{tabular}

Link yang telah dituliskan oleh siswa terdiri dari lima kategori meliputi: (1) Jenis (type of), (2) bagian dari (part to), (3) petunjuk (lead to), (4) sifat (characteristic), (5) bukti (evidence). Link yang paling banyak dikuasai oleh siswa terdiri dari: bagian dari (88.88\%) misalnya: Larutan asam mempunyai kekuatan asam dan larutan basa mempunyai kekuatan basa. Link terbanyak pada urutan kedua adalah sifat (87.38\%), misalnya larutan elektrolit bersifat penghantar listrik sedangkan larutan nonelektrolit bersifat bukan penghantar listrik, dan lain-lain. Sedangkan pada urutan ketiga adalah link jenis dari $(80.55 \%)$, misalnya larutan dapat berupa larutan elektrolit dan larutan nonelektrolit, dan lain-lain. Pada urutan keempat yaitu link petunjuk $(72.22 \%)$, misalnya kekuatan asam ditentukan oleh tetapan ionisasi asam dan $\mathrm{pH}$, dan lain-lain. Pada urutan kelima yaitu link bukti $(66.66 \%)$, contohnya larutan garam dapat mengalami ionisasi.

Proposisi dari konsep yang dituliskan oleh siswa sangat beragam. Salah satu contohnya adalah larutan garam dapat menjadi ionisasi, sedangkan siswa lain menuliskan bahwa larutan garam mempunyai ionisasi. contoh lain dari penulisan proporsi yaitu, ada siswa yang menuliskan bahwa larutan berupa larutan 
elektrolit dan larutan nonelektrolit, dan siswa lain menuliskan larutan terdiri dari larutan elektrolit dan larutan nonelektrolit.

Ada beragam variasi konsepsi dari siswa yang menjawab dengan benar dan salah. Proporsi yang benar adalah dua konsep yang terhubung dengan frasa penghubung yang sesuai dengan konsepsi ilmiah. Dua konsep yang tidak terhubung atau dan konsep yang terhubung dengan frasa yang salah dikatakan sebagai proporsi yang salah, sedangkan dua konsep yang terhubung tidak sesuai dengan konsepsi ilmiah dikatakan sebagai miskonsepsi. Oleh karena itu peta konsep juga dapat menunjukkan miskonsepsi siswa pada pokok bahasan larutan asam-basa. Berdasarkan hasil identifikasi dari proporsi yang dituliskan oleh siswa yaitu sebagai berikut.

a. Konsep-konsep Larutan asam-basa yang paling banyak dikuasai oleh sebanyak $94 \%$ siswa adalah Larutan elektrolit yang bersifat sebagai penghantar listrik, dan larutan nonelektrolit bersifat bukan penghantar listrik.

b. Konsep-konsep larutan asam-basa yang dikuasai oleh sebanyak $83 \%$ siswa adalah larutan elektrolit dapat berupa larutan asam, larutan basa, dan larutan garam. Serta larutan asam mempunyai kekuatan asam dan larutan basa mempunyai kekuatan basa.

c. Konsep-konsep yang dikuasai oleh sebanyak $77 \%$ siswa adalah Larutan berupa larutan elektrolit dan larutan nonelektrolit.

d. Konsep-konsep yang dikuasai oleh sebanyak $72 \%$ siswa adalah larutan garam bersifat asam, basa, netral. Serta kekuatan ionisasi asam ditentukan oleh tetapan ionisasi asam dan $\mathrm{pH}$ larutan, dan tetapan ionisasi basa ditentukan oleh tetapan ionisasi basa dan $\mathrm{pH}$ larutan.

e. Konsep-konsep yang dikuasai oleh sebanyak $61 \%$ siswa adalah larutan garam dapat mengalami ionisasi.

Beberapa miskonsepsi yang dapat dilihat dari proporsi yang terhubung salah pada peta konsep larutan asam-basa antara lain:

a. Larutan garam mempunyai ionisasi, dan larutan garam bersifat asam, basa, dan netral. Salah satu siswa menuliskan bahwa ionisasi yang bersifat asam, basa, dan netral. Dalam hal ini nampak adanya miskonsepsi siswa pada larutan garam.

b. Kekuatan asam ditentukan oleh tetapan ionisasi asam dan $\mathrm{pH}$ larutan, salah satu siswa menjawab bahwa tetapan ionisasi asam ditentukan oleh kekuatan asam dan pH larutan. Dapat dilihat bahwa adanya miskonsepsi siswa mengenai kekuatan asam.

c. Kekuatan basa ditentukan oleh tetapan ionisasi basa dan $\mathrm{pH}$ larutan, salah satu siswa menjawab bahwa tetapan ionisasi basa ditentukan oleh kekuatan basa dan $\mathrm{pH}$ larutan. Dalam hal ini juga nampak adanya miskonsepsi siswa terhadap kekuatan basa.

\section{Kognitif siswa berdasarkan aspek isi}

Aspek isi dari kognitif siswa pada konsep larutan asam-basa yang diperoleh dari jawaban atas soal dalam peta konsep, pencapaian skor mulai 0 sampai 40. Pada aspek isi ini skor terendah yang diperoleh siswa adalah 11 dari subyek AG, skor tertinggi yang diperoleh siswa adalah 40 dari subyek AR, FL, LR, PS, SH, NR, IP, dan VP. Selanjutnya berdasarkan perolehan skor tiap subyek penelitian dapat dibuat tabel distribusi frekuensi pada aspek isi. Distribusi frekuensi skor aspek isi disajikan pada Tabel 3.

Tabel 3. Distribusi frekuensi skor aspek isi

\begin{tabular}{llll}
\hline Rentang & Kategori & F & $\%$ \\
\hline $0-10$ & Kurang Sekali & 0 & 0 \\
$11-20$ & Kurang & 3 & 16,66 \\
$21-30$ & Baik & 2 & 11.11 \\
$31-40$ & Baik Sekali & 13 & 72.22 \\
\hline
\end{tabular}

Berdasarkan tabel 3 tidak terdapat subyek pada rentang 0-10 artinya tidak ada siswa pada kategori kurang sekali. Pada rentang skor 11-20 dengan kategori kurang terdapat 3 subyek artinya ada $16.66 \%$ dari seluruh siswa yang memiliki kategori kurang. Pada rentang skor 21-30 dengan kategori baik terdapat 2 subyek, artinya ada $11.11 \%$ dari seluruh siswa yang memiliki kategori baik. Selanjutnya pada rentang 31-40 dengan kategori baik sekali terdapat 13 subyek artinya ada $72.22 \%$ dari seluruh siswa yang berkategori baik sekali. 


\section{Ucapan terimakasih}

Disampaikan banyak terima kasih kepada seluruh dosen di Jurusan Kimia Fakultas Matematika dan Ilmu Pengetahuan Alam Universitas Negeri Manado dan juga SMA Pioner Manado yang berperan penting dalam pelaksanaan penelitian ini.

\section{Kesimpulan}

Berdasarkan hasil identifikasi dan pembahasan diketahui bahwa konsepsi siswa yang ditangkap dari hasil peta konsep buatan siswa diperoleh bahwa siswa dapat memahami dengan baik konsep Larutan asam-basa.

\section{Daftar Pustaka}

1. Qing, Z., Wang, T., Zheng, Q. Probing high school students' cognitive structures and key areas of learning difficulties on ethanoic acid using the flow map method. Chem. Educ. Res. Pract., 2015, 16, 589-602. DOI.

2. Mutakin, C. Pengembangan evaluasi peta konsep sebagai alat ukur struktur kognitif siswa kelas VIII MTs pada pokok bahasan getaran dan gelombang. Skripsi, Semarang: Universitas Negeri Semarang, 2011.

3. Shavelson R. J. Some aspects of the correspondence between content structure and cognitive structure in physics instruction, J. Educ. Psychol., 1972. 63, 225-234.

4. Bonder, G. M. Contructivism: a theory of knowledge. J. Chem. Educ. 1986, 63, 10, 873. DOI

5. Jamaris, M. Perkembangan dan Pengembangan Anak Usia Taman KanakKanak. Gramedia : Jakarta, Indonesia, 2006. ISBN

6. Flavell, J. H. Development of children's knowledge about the mental world. International Journal of Behavioral Development, 2000, 24 (1), 15-23. http://dx.doi.org/10.1080/016502500383421 